\title{
RELATIONSHIP UNDERSTANDING BETWEEN PERFORMANCE APPRAISAL, SUCCESSION PLANNING, AND CAREER DEVELOPMENT
}

\author{
Sheeba Ramola ${ }^{1 凶}$, Prof. Santosh Rangnekar ${ }^{2}$ \\ ${ }^{1}$ Research Scholar, Department of Management Studies, Indian Institute of Technology Roorkee, \\ Roorkee, Uttarakhand, India \\ 2 Professor, Department of Management Studies, Indian Institute of Technology Roorkee, Roorkee, \\ Uttarakhand, India
}

DOI: https://doi.org/10.29121/ijetmr.v8.i2.2021.848

Article Citation: Sheeba Ramola, and Prof. Santosh Rangnekar. (2021). RELATIONSHIP UNDERSTANDING BETWEEN PERFORMANCE APPRAISAL, SUCCESSION PLANNING, AND CAREER DEVELOPMENT. International Journal of Engineering Technologies and Management Research, 8(2), 1-8. https://doi.org/10.29121/ijetmr.v8 i2 2021.848

Published Date: 08 February 2021

Keywords:

Performance Appraisal

Succession Planning

Career Development

Indian Organizations

\section{ABSTRACT}

Purpose: This paper aims to explore an integrated relationship between performance appraisal, succession planning, and career development in the Indian context. A very few empirical studies could be seen in identifying a relationship between the proposed variables.

Design/methodology/approach: An empirical study was conducted by employing the cross-sectional survey-based research design along with the convenience sampling method. Around, 167 questionnaires were circulated through online via Google forms. Finally, 134 responses were received from respondents having $80.23 \%$ response rate. The responses were subject to analysis using normality check, confirmatory factor analysis, correlation, model fit and multiple hierarchical regression analysis.

Findings: Results reveal that all three study variables are positively associated with each other. This study fully supports the applicability of performance appraisal, and succession planning as crucial predictors of career development more specifically in the Indian context.

Research limitations/implications: This current study is conducted using online data collection procedure, while future studies may use indepth interview and daily diary studies.

Practical implications: This study exhibits how employee career development can be initiated through succession planning and performance appraisal. This study also suggested that the organizations which emphasize on an effective policy guideline for systematic performance appraisal will probably support the succession planning and career development.

Originality/value: Notably, no prior studies empirically investigate the proposed relationship in Indian context. Furthermore, the findings serve as a policy guideline for the performance appraisal, succession planning and career development literature in an Indian organizational setting. 


\section{INTRODUCTION}

The key emphasize of performance appraisal research from organizational psychology has been to explore different types of performance appraisal techniques and its relationship with organizational performance (Fletcher, 2001). Furthermore, literature on performance appraisal in organization tends to stress on the different models in which nature of performance appraisal has been given major attention, but a very few studies have paid crucial attention to explore relationship with succession planning and career development. For instance, research by Edwards and Williams (1998) suggest that performance appraisal can have positive association with the succession planning and career development. Despite the fact, there is a lack of literature on studying the influence of performance appraisal on succession planning and career development. This study stress on advance understanding on the proposed relationship more specifically in the Indian context. The conceptual model is highlighted in Figure 1 below.

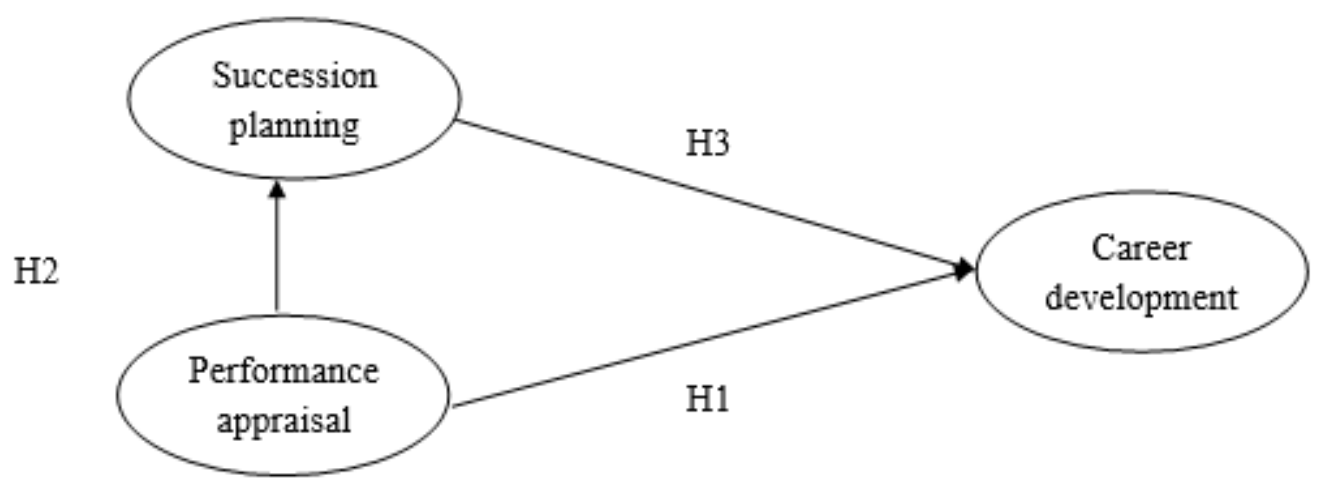

Figure 1: Conceptual framework

\section{PERFORMANCE APPRAISAL AND CAREER DEVELOPMENT}

According to ESuper (1980) career implies as the integration of various role played by individual across its lifetime at work. The role that involves student, citizen, worker, homemaker, and pensioner positions which are directly or indirectly associated with the specified expectations that is eventually possesed by almost all individuals in various phase of life. But it is pertinent to mention that individual has clear vision to their career path that supports activities for career development. Another research explains that career development is the lifelong process that involves managing leisure, work, learning and different transition of life which in turn achieve the personally desired and evolving future (Pope, 2009). A noteworthy research by Hauser Sheridan, and Warren, (1999) argued that around 75 percent of managers commonly experiences culture shock, out of mind, and out of sight syndrome. Therefore, to overcome such situations, mentoring, performance appraisal and succession planning are likely to plays a crucial role in steping towards right career development. Research suggested that career development is an integral part of talent management (Stahl et al., 2012). In addition to this, the talent management is largely focus on recruitment, succession planning, staffing, retention and training and development (Stahl et al, 2007). According to Beechler and Woodward (2009) talent is the sum of individuals various abilities such as skills, experience, knowledge, attitude, judgement, character, intelligence, drive and intrinsic guts that commonly supports in getting the right path for career development. Additionally, many studies have been conducted on career development in relationship to how mentoring influence the career development. For instances, many primitive studies reported that the career development is largely influenced by the relationship of an employee with the mentors and peers (Dalton, Thompson, \& Price, 1977; Levinson, Darrow, Klein, Levinson, \& McKee, 1978). Despite the fact, no prior study explicitly states about the role of performance appraisal on career development. On contrast, there have been only few studies on performance appraisal (Arvey \& Murphy, 1998). Research on performance appraisal broadly suggested that the appraisal is largely associated with the task performance aspects such as core responsibilities and job-specific behaviour; where contextual performance commonly accounts for non-job-specific behaviour such as dedication, cooperation, persistence and enthusiasm (Organ, 1997). Further, contextual performance is related to those attributes which go beyond the specific task requirement, which eventually uplift the positive behaviour and 
leads to effective climate within the organization (Schmidt, 1993). Besides this, task performance details about the individual cognitive capacity, experience and skills, whereas contextual performance entails about the individual motivation and their personality (Conway, 1999). This study argued that those organizations which executed the implementation of both task and contextual performance are likely to provide a better career development. Because, individual who is self-motivated and have positive personality trait more often leads to effectively utilizing their skills and knowledge in optimum way that eventually supports the career development. Another possible argument is that any organization having multi-feedback system commonly leads to identify individual self-awareness, notably self-awareness is integral part of emotional intelligence which eventually leads to better career development. On the basis of above discussion, this study hypothesis that

H1: Performance appraisal is positively associated with career development

\subsection{PERFORMANCE APPRAISAL AND SUCCESSION PLANNING}

Many previous studies have widely examined the role of performance appraisal in different ways. But all of the studies have a central theme on identify the performance of the individual and organization. A noteworthy study by Dweck and Leggett (1988) suggested that two form of orientation that is performance goal orientation and learning goal orientation. The learning goal approach entirely stress on to develop new competence within the individual through learning new knowledge and skills that ultimately supports in mastering over the problems and various challenges. Whereas the performance goal approach emphasizes on the competence by seeking favourable assessment and avoiding criticism. Importantly, VandeWalle and Cummings (1997) suggested that learning goal approach is positively associated with the feedback seeking whereas performance goal approach is negatively associated with the feedback. Furthermore, another research suggested that learning goal is also positively linked to self-efficacy. Succession planning implies as a systematic effort to identify the leadership requirements that eventually supports in identifying the pool of potential individual through training and learning opportunitites provided to them (Hor et al., 2010). Moreover, succession planning is all about finding future successors and leaders (Cameron et al., 2007). Thus, the utmost important task for the organization is to continuously develop, identify and choose the successors who probably will be the right person with the appropriate skills for upcoming organizational requirements (Collins, 2001). Notably, the leadership competencies are continuously reviewed, identified and updated against the established competencies set by organization through performance appraisal. This study argued that the organization having learning goal approach is likely to enhance the individual self-efficacy. Research suggested that individual having the self-efficacy is more likely to exhibit high self-esteem, and positive self-view this ultimately supports the individual in becoming the next successor within the organization. Conclusively, this study proposed that organization having a systematic performance appraisal with goals to develop an employee possibly leads to succession planning. On the above rational, this study hypothesizes that

H2: Performance appraisal is positively associated with succession planning.

\subsection{SUCCESSION PLANNING AND CAREER DEVELOPMENT}

Talent management is widely considered as the utmost important aspect in any organization with respect to its performance and sustainable growth (McDonnell and Collings, 2011). Stahl et al (2012) reported that many organizations follow the talent pool strategy. Under the umbrella of talent pool strategy that encompasses of training, development, succession planning, retention and recruitment eventually supports to those best practice and policy that leads to accelerate their performance and development which in turn leads to career development of an employee and organizational development as a whole. Therefore, under talent pool identified talented employees are provide special attention with respect to different career path based on their skills and competencies required to achieve the current and future organizational goals (Demirbag, \& Riddle, 2011). Furthermore, there is imperative necessity of cultural fit between the employee and the organization (Stahl et al., 2007). However, research suggested that the talent management lead to effective succession planning. This study argued that organizations consistently emphasize on effective succession planning which in turn support better employee career development. Furthermore, succession planning is inherently embodied within talent management (Thunnissen et al., 2013) and talent management in itself put a huge attention to develop, attract and retain the talents which ultimately supports the employee career development. Importantly, the study by Hor et al (2010) attempted to suggested that succession 
Relationship Understanding Between Performance Appraisal, Succession Planning, and Career Development

planning not only look forward to develop the next successors but also supports individual to identify their career paths through effective training and development programs with an objective to provide better career development. Therefore, while considering the above-mentioned background, this study proposed that the effective succession planning within the organization will ultimately lead to support the individual for better career development more specifically in the Indian context among Indian executives. Hence, this study hypothsize that:

H3: Succession planning is positively associated with career development

\section{RESEARCH METHODOLOGY}

The data for this current study was collected from 167 Indian executive from different parts of India. This study employed the cross-sectional survey-based research design along with convenience sampling method. The survey was administered through online google forms and the responses were collected immediately after the completion of the forms. The questionnaire included information regarding gender, age, and hierarchical position in the organization. This study employed the closed-ended questions and various techniques have been employed to test various hypothesis. This study performed confirmatory factor analysis to check the validation for the all scales more specifically in the context of Indian executives. This study checks the convergent and discriminant validity. The multiple hierarchy regression analysis has been employed to test the variance explained by one dependent to another independent variable. The talent management scale by (Brinsnav \& Rangnekar, 2011) was adopted for measuring the succession planning (5 items), performance appraisal ( 7 items), and career development (5 items). The respondent's evaluated the questions on a response scale of "1" as "strongly disagree" and "7" as "strongly agree". Further, this study controls the variables age (years): (1) indicates 21-30 years of age, (2) indicates 30-40 years of age, (3) indicates 40-50 years of age, (4) indicates 50-60 years of age; gender: (1) for male, (2) for female; hierarchical level: (1) for junior, (2) for middle, and (3) for senior level.

\section{ANALYSIS AND RESULTS}

This study performed Confirmatory factor analysis (CFA) to check that study variables displayed distinct constructs in the Indian organizational setting (Nehra, 2018; Nehra \& Rangnekar, 2016; Nehra \& Rangnekar, 2017; Nehra \& Rangnekar, 2018). According to Anderson and Gerbing (1988), suggested that to check the absolute and relative fit indices to identify the model fit. Thus, this study compares the hypothesized model with one, two and three factor model. This study employed self-reported measures thus there is possibility of common-method bias. Hence, the study utilized Harman's single factor test (Podsakoff and Organ, 1986). Results reported that single factor test contributed less than $50 \%$ variance that demonstrates no issue of common-method bias. This study using SPSS v21.0. Table I shows the standard deviation, correlation, mean and reliability of the constructs. Table II displays the normality statistics of the study variables. Table III demonstrates the model fit indices of one, two and three factor model. Table IV, V and VI exhibits the multiple hierarchy regression analysis between the study variables. Further, Table VII demonstrates the convergent and discriminate validity along with validation of talent management scle among Indian executives. Table I demonstrates that performance appraisal has a positive correlation with succession planning $(r=0.72, p<0.01)$ and career development $(r=0.20, p<0.05)$; and succession planning is also positive correlation with career development $(\mathrm{r}=0.24, \mathrm{p}<0.01)$. Further, Table III exhibits CFA for three-factor model shows better fit indices with $\mathrm{X}^{2}=173.319(\mathrm{df}=114), \mathrm{p}<0.05$; RMSEA $=0.06$, CFI $=0.96, \mathrm{GFI}=0.87$ and IFI $=$ 0.96 in Indian context. Table IV, V and VI exhibits multiple hierarchy regression analysis results shows that performance appraisal explaining for $52.9 \%$ variance in succession planning $(\beta=0.750, p<0.001)$; further, succession planning explaining for $4.7 \%$ variance in career development $(\beta=0.254, \mathrm{p}<0.05)$; and finally, performance appraisal explaining for $3.6 \%$ variance in career development $(\beta=0.238, \mathrm{p}<0.001)$. The results established the full supports for the $\mathrm{H} 1, \mathrm{H} 2$ and $\mathrm{H} 3$ in this study. 
Table 1: The means, standard deviations, and correlations

\begin{tabular}{|c|c|c|c|c|c|c|c|c|}
\hline & Mean & SD & Age & Gender & Hierarchy & PA & SP & CD \\
\hline Age & 2.16 & 0.97 & --- & & & & & \\
\hline Gender & 1.13 & 0.34 & -0.02 & --- & & & & \\
\hline Hierarchy & 2.36 & 0.77 & $0.20^{*}$ & 0.11 & --- & & & \\
\hline PA & 4.92 & 1.24 & 0.14 & -0.04 & 0.10 & {$[0.89]$} & & \\
\hline SP & 4.56 & 1.44 & 0.02 & -0.02 & -0.05 & $0.72^{* *}$ & {$[0.92]$} & \\
\hline CD & 5.61 & 0.95 & -0.03 & 0.05 & 0.07 & $0.20^{*}$ & $0.24^{* *}$ & {$[0.82]$} \\
\hline
\end{tabular}

Notes: ${ }^{* *} p<0.01 ;{ }^{*} p<0.05 ; n=256, \mathrm{M}=$ mean; $\mathrm{SD}=$ standard deviations; PA = performance appraisal; $\mathrm{SP}=$ succession planning; $\mathrm{CD}$ = career development; the Cronbach's values are present against the diagonal

Table 2: Normality statistics

\begin{tabular}{|c|c|c|c|}
\hline & PA & SP & CD \\
\hline $\mathrm{n}$ & 134 & 134 & 134 \\
\hline Skewness & -0.621 & -0.528 & -0.584 \\
\hline Std Error & 0.209 & 0.209 & 0.209 \\
\hline Kurtosis & 0.032 & -0.374 & 0.139 \\
\hline Std Error & 0.417 & 0.417 & 0.417 \\
\hline
\end{tabular}

Notes: $\mathrm{PA}=$ Performance appraisal; $\mathrm{SP}=$ Succession planning; $\mathrm{CD}=$ Career development

Table 3: Models fit indices

\begin{tabular}{|c|c|c|c|c|c|c|c|c|}
\hline Models & $\mathrm{X}^{2}$ & $d f$ & $\Delta \mathrm{X}^{2}$ & $\boldsymbol{\Delta} d f$ & RMSEA & CFI & CFI & IFI \\
\hline Three-factor model $^{\mathrm{a}}$ & 173.319 & 114 & & & 0.06 & 0.96 & 0.87 & 0.96 \\
\hline Two-factor model & 320.704 & 118 & 147.385 & 4 & 0.11 & 0.85 & 0.74 & 0.86 \\
\hline One-factor model & 544.612 & 119 & 223.980 & 2 & 0.16 & 0.70 & 0.62 & 0.70 \\
\hline
\end{tabular}

Notes: $n=134$, aHypothesized model

Table 4: Multiple hierarchical regression analysis of performance appraisal to predict succession planning

\begin{tabular}{|c|c|c|}
\hline & \multicolumn{3}{|c|}{ Succession planning } \\
\hline & $\beta$ & $\beta$ \\
\hline Predictors & Step 1 & Step 2 \\
\hline Step 1 & & \\
\hline Age & 0.032 & -0.093 \\
\hline Gender & -0.016 & 0.012 \\
\hline Hierarchical level & -0.065 & 0.038 \\
\hline Step 2 & & \\
\hline Performance appraisal & & $0.750^{* * *}$ \\
\hline R2 & 0.005 & $0.544^{* * *}$ \\
\hline$\Delta$ R2 & - & $0.529^{* * *}$ \\
\hline
\end{tabular}

Notes: ${ }^{* * *} p<0.001 ;{ }^{* *} p<0.01 ;{ }^{*} p<0.05 ; n=134$, table shows the standardized $\beta$ coefficients

Table 5: Multiple hierarchical regression analysis of succession planning predicts to career development

\begin{tabular}{|c|c|c|}
\hline & \multicolumn{3}{|c|}{ Career development } \\
\hline & $\beta$ & $\beta$ \\
\hline Predictors & Step 1 & Step 2 \\
\hline Step 1 & & -0.063 \\
\hline Age & -0.054 & 0.057 \\
\hline Gender & 0.053 & 0.101 \\
\hline Hierarchical level & 0.085 & \\
\hline Step 2 & & $0.254^{*}$ \\
\hline Succession planning & & \\
\hline
\end{tabular}


Relationship Understanding Between Performance Appraisal, Succession Planning, and Career Development

\begin{tabular}{|c|c|c|}
\hline $\mathrm{R} 2$ & 0.011 & $0.076^{*}$ \\
\hline$\Delta \mathrm{R} 2$ & - & $0.047^{*}$ \\
\hline
\end{tabular}

Notes: ${ }^{* * *} p<0.001 ;{ }^{* *} p<0.01 ;{ }^{*} p<0.05 ; n=134$, table shows the standardized $\beta$ coefficients

Table 6: Multiple hierarchical regression analysis of performance appraisal predicts to career development

\begin{tabular}{|c|c|c|}
\hline & Career development \\
\hline & $\beta$ & $\beta$ \\
\hline Predictors & Step 1 & Step 2 \\
\hline Step 1 & & -0.096 \\
\hline Age & -0.054 & 0.062 \\
\hline Gender & 0.053 & 0.117 \\
\hline Hierarchical level & 0.085 & \\
\hline Step 2 & & $0.238^{* * *}$ \\
\hline Performance appraisal & & $0.066^{* * *}$ \\
\hline R2 & 0.011 & $0.036^{* * *}$ \\
\hline$\Delta$ R2
\end{tabular}

Notes: ${ }^{* * *} p<0.001 ; n=134$, table shows the standardized $\beta$ coefficients

Table 7: Validation of Talent Management scale in Indian context

\begin{tabular}{|c|c|c|c|c|c|c|c|}
\hline Items & Mean & SD & FL & CR & AVE & MSV & ASV \\
\hline Pa1 & 4.76 & 1.58 & .76 & & & & \\
\hline$P a 2$ & 4.42 & 1.82 & .55 & & & & \\
\hline$P a 3$ & 5.10 & 1.49 & .80 & & & & \\
\hline$P a 4$ & 4.67 & 1.73 & .78 & & & & \\
\hline$P a 5$ & 5.60 & 1.35 & .71 & .89 & .55 & .52 & .34 \\
\hline$P a 6$ & 5.16 & 1.48 & .78 & & & & \\
\hline$P a 7$ & 4.73 & 1.66 & .78 & & & & \\
\hline$S p 1$ & 4.76 & 1.64 & .88 & & & & \\
\hline$S p 2$ & 4.61 & 1.64 & .89 & & & & \\
\hline$S p 3$ & 4.75 & 1.56 & .89 & .92 & .76 & .62 & .35 \\
\hline$S p 4$ & 4.04 & 1.76 & .78 & & & & \\
\hline$S p 5$ & 4.62 & 1.59 & .82 & & & & \\
\hline$C d 1$ & 5.81 & 1.10 & .65 & & & & \\
\hline$C d 2$ & 5.42 & 1.36 & .57 & & & & \\
\hline$C d 3$ & 5.45 & 1.38 & .70 & .83 & .51 & .08 & .07 \\
\hline$C d 4$ & 5.55 & 1.23 & .91 & & & & \\
\hline$C d 5$ & 5.85 & 1.08 & .73 & & & & \\
\hline
\end{tabular}

Notes: $n=134, \mathrm{~Pa}=$ performance appraisal items, $\mathrm{Sp}=$ succession planning items, $\mathrm{Cd}=$ career development items, $\mathrm{SD}=$ standard deviation, $\mathrm{FL}=$ factor loading, $\mathrm{CR}=$ composite reliability, $\mathrm{AVE}=$ average variance extracted, $\mathrm{MSV}$ $=$ maximum shared variance, $\mathrm{ASV}=$ average shared variance

\section{DISCUSSION}

More importantly, researchers do not yet know the extent to which the relationship exists between the performance appraisal, succession planning and career development more specifically in the Indian context. This study contributes to existing body of literature by empirically testing on the proposed relationship among Indian executives. To the best of researchers knowledge, the current study is one of its kind to empirically examines the influence of performance appraisal on succession planning and career development among the Indian executives. Further, the proposed model of this study fully support the entire hypothesis H1, H2 and H3.

H1 questioned positive relationship between performance appraisals with succession planning. Key concern of this study, is that performance appraisal is significantly related to succession planning. The possible explanation for 
this finding is that performance appraisal is a systematic process that involves behavioural and job-related traits which is in relative comparison to the performance standard and behavioural requirement for a specific job as desired by the organization. Further, performance appraisal supports the identification of potential best performer and the least performer that ensure the kind of advance training development programs required for the career development of the potentials leaders to develop the skills s per the current and expected future need $f$ the organization. Therefore, an accurate and unbiased evaluation of performance appraisal is likely to give more fruitful outcome in terms of identifying the future successor within the organization to meet the future organization needs.

$\mathrm{H} 2$ questioned the positive association with succession planning and career development. The findings reported that succession planning is positively associated with career development more specifically among Indian executives. The possible explanation of such findings may be because when individual has a clear vision about the future succession plans of the organization through a growth plan well in place in a systematic and organized manner, will lead an employee to work on self-development of the individual and shows the ability to learn new knowledge and skills in a more effective way leading to an effective career development. In this sense the findings is well justified that succession planning is positively associated with career development.

H3 questioned that performance appraisal leads to career development. The possible reason of such findings is that when an individual has a clear view about their strength and weakness only then he/she will probably choose the best option for themselves to build their career in alignment with their strength and weakness. Further, performance appraisal helps to identify the potential areas where is individual has his expertise and where the individual needs more development which can be acquired through various training and development program that eventually leads to better career development. This study also suggests that managers effectively evaluate the performance of employees with respect to job and behavioural trait that ultimately supports better succession planning and career development. This study also recommends mixed-mode approaches for future research studies. Further, the sample of this study is largely taken from manufacturing sector, therefore, it is not possible to generalize these results to another sector. Thus, this study recommended future research studies on the proposed relationship in different sector such as in healthcare, information technology, tourism and many more. This study also suggests to employ longitudinal research design for future research studies. This study conclusively recommended that taken the data from focus groups, interview and daily dairy studies provides the advance understanding on the proposed items more specifically in the context of India executives.

\section{SOURCES OF FUNDING}

This research received no specific grant from any funding agency in the public, commercial, or not-for-profit sectors.

\section{CONFLICT OF INTEREST}

The author have declared that no competing interests exist.

\section{ACKNOWLEDGMENT}

None.

\section{REFERENCES}

[1] Anderson, J. C., \& Gerbing, D. W. (1988). Structural equation modeling in practice: A review and recommended two-step approach. Psychological bulletin, 103(3), 411.

[2] Arvey, R. D., \& Murphy, K. R. (1998). Performance evaluation in work settings. Annual review of psychology, 49(1), 141-168.

[3] Beechler, S., \& Woodward, I. C. (2009). The global "war for talent”. Journal of international management, 15(3), 273-285.

[4] Conway, J. M. (1999). Distinguishing contextual performance from task performance for managerial jobs. Journal of applied Psychology, 84(1), 3.

International Journal of Engineering Technologies and Management Research 
Relationship Understanding Between Performance Appraisal, Succession Planning, and Career Development

[5] Collins, J. C., \& Collins, J. (2001). Good to great: Why some companies make the leap... and others don't. Random House.

[6] Cameron, L., \& Larsen-Freeman, D. (2007). Complex systems and applied linguistics. International journal of applied linguistics, 17(2), 226-239.

[7] Dalton, G. W., Thompson, P. H., \& Price, R. L. (1977). The four stages of professional careers-A new look at performance by professionals. Organizational dynamics, 6(1), 19-42.

[8] Dweck, C. S., \& Leggett, E. L. (1988). A social-cognitive approach to motivation and personality. Psychological review, 95(2), 256.

[9] Edwards, R. G., \& Williams, C. J. (1998). Performance appraisal in academic libraries: minor changes or major renovation? Library Review, 47(1), 14-19.

[10] Fletcher, C. (2001). Performance appraisal and management: The developing research agenda. Journal of Occupational and organizational Psychology, 74(4), 473-487.

[11] Hauser, R. M., Sheridan, J. T., \& Warren, J. R. (1999). Socioeconomic achievements of siblings in the life course: New findings from the Wisconsin Longitudinal Study. Research on Aging, 21(2), 338-378.

[12] Hor, Y. S. (2010). YS Hor, AJ Williams, JG Checkelsky, P. Roushan, J. Seo, Q. Xu, HW Zandbergen, A. Yazdani, NP Ong, and RJ Cava, Phys. Rev. Lett. 104, 057001 (2010). Phys. Rev. Lett., 104, 057001.

[13] Levinson, D. J. with Darrow, CN, Klein, EB, Levinson, MH, \& McKee, B. (1978). The seasons of a man's life.

[14] Mellahi, K., Demirbag, M., \& Riddle, L. (2011). Multinationals in the Middle East: Challenges and opportunities. Journal of World Business, 46(4), 406-410.

[15] McDonnell, A., \& Collings, D. G. (2011). The identification and evaluation of talent in MNEs (Doctoral dissertation, Routledge).

[16] Nehra, N. S., \& Rangnekar, S. (2016, December). Relationship understanding between social adjustment and self-disclosure-results from the Indian power sector. In 16thGlobal Conference on Flexible Systems and Flexibility (pp. 256-266).

[17] Nehra, N. S. (2018). Does Locus of Control Mediate the Relationship Between Personality Integration and SelfDisclosure? In Harnessing Human Capital Analytics for Competitive Advantage (pp. 245-264). IGI Global.

[18] Nehra, N. S., \& Rangnekar, S. (2017). Relationship Understanding Between Emotional Stability, Self-Disclosure and Social Adjustment. Journal of Intercultural Communication Research, 46(6), 558-578.

[19] Nehra, N. S., \& Rangnekar, S. (2018). Linking the emotional maturity factors and self-disclosure: A study of Indian organizations. International Journal of Organizational Analysis, 26(2), 255-281.

[20] Organ, D. W. (1997). Organizational citizenship behavior: It's construct clean-up time. Human performance, 10(2), 85-97.

[21] Pope, M. (2009). Jesse Buttrick Davis (1871-1955): Pioneer of vocational guidance in the schools. The Career Development Quarterly, 57(3), 248-258.

[22] Podsakoff, P. M., \& Organ, D. W. (1986). Self-reports in organizational research: Problems and prospects. Journal of management, 12(4), 531-544.

[23] Schmidt, M. W., Baldridge, K. K., Boatz, J. A., Elbert, S. T., Gordon, M. S., Jensen, J. H., ... \& Windus, T. L. (1993). General atomic and molecular electronic structure system. Journal of computational chemistry, 14(11), 13471363.

[24] Stahl, G. K., Chua, C. H., \& Pablo, A. L. (2012). Does national context affect target firm employees' trust in acquisitions? Management International Review, 52(3), 395-423.

[25] Stahl, G. K., Chua, C. H., Caligiuri, P., Cerdin, J. L., \& Taniguchi, M. (2009). Predictors of turnover intentions in learning-driven and demand-driven international assignments: The role of repatriation concerns, satisfaction with company support, and perceived career advancement opportunities. Human Resource Management: Published in Cooperation with the School of Business Administration, The University of Michigan and in alliance with the Society of Human Resources Management, 48(1), 89-109.

[26] Super, D. E. (1980). A life-span, life-space approach to career development. Journal of vocational behavior, 16(3), 282-298.

[27] Thunnissen, M., Boselie, P., \& Fruytier, B. (2013). Talent management and the relevance of context: Towards a pluralistic approach. Human Resource Management Review, 23(4), 326-336.

[28] VandeWalle, D., \& Cummings, L. L. (1997). A test of the influence of goal orientation on the feedback-seeking process. Journal of Applied psychology, 82(3), 390. 